\title{
CLINICAL AND MOLECULAR-GENETIC PROFILES OF PATIENTS WITH MORPHOLOGICAL INDICATIONS OF CONGENITAL MULTICORE MYOPATHY
}

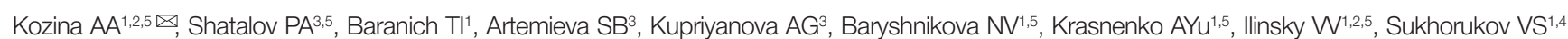

${ }_{1}^{1}$ Pirogov Russian National Research Medical University, Moscow, Russia

2 Orekhovich Institute of Biomedical Chemistry, Moscow, Russia

${ }^{3}$ Veltischev Research and Clinical Institute for Pediatrics, Pirogov Russian National Research Medical University, Moscow, Russia

${ }^{4}$ Research Center of Neurology, Moscow, Russia

${ }^{5}$ Genotek Ltd., Moscow, Russia

Congenital core myopathies are a clinically and genetically heterogenous group of congenital myopathies that share a specific histopathological feature: areas of reduced oxidative activity in muscle fibers. The relationship between clinical, genetic and morphological characteristics of this group of disorders remains understudied. The aim of this work was to compare clinical presentations and morphological phenotypes of patients with congenital myopathies/myodystrophy to the data yielded by massively parallel exome sequencing. Eight children were included in the study: 2 boys and 6 girls aged 3 to 14 years. Their biopsy material was analyzed by light and electron microscopy. Sequencing was performed on HiSeq2500. Mutations were detected in 7 (87.5\%) of 8 participants. Six children had 8 mutations in the genes associated with congenital core myopathies; one patient had 2 mutations in the LAMA2 gene implicated in merosin-deficient muscular dystrophy. The proportions of patients with mutations in RYR1 and SEPN1 were equal (42.86\%). Of 10 detected mutations, 3 had not been previously described, including c.7561G>A in RYR1, c.485C>A in SEPN1 and p.Cys1136Arg in LAMA2. The clinical and morphological features of core myopathies suggest that genetic causes of this group of disorders should not be limited to RYR1 and SEPN1 genes only. This necessitates the search for and the study of other genes implicated in congenital myopathies or myodystrophy using state-of-the-art molecular genetic tools.

Keywords: congenital central core disease, congenital multicore myopathies, RYR1 gene, SEPN1 gene, LAMA2 gene, muscle biopsy, exome sequencing

Author contribution: Kozina AA — literature analysis, analysis and interpretation of exome sequencing data, manuscript preparation; Shatalov PA — data acquisition, microscopy, manuscript preparation; Baranich TI - microscopy; Artemieva SB - medical histories and neurological examinations;

Kupriyanova AG — clinical data acquisition; Baryshnikova NV — literature analysis, analysis and interpretation of exome sequencing data, manuscript preparation; Krasnenko AYu — exome sequencing; llinsky W — exome sequencing; Sukhorukov VS — study design, data acquisition.

Compliance with ethical standards: the study was approved by the Ethics Committee of Pirogov Russian National Research Medical University (Protocol № 172 dated February 19, 2018). All participants or their legal representatives gave informed consent to participate.

Correspondence should be addressed: Anastasia A. Kozina

Nastavnichesky per. 17, bld. 1, Moscow, 105120; doctor@genotek.ru

Received: 07.02.2019 Accepted: 19.04.2019 Published online: 30.04.2019

DOI: $10.24075 /$ brsmu.2019.034

\section{КЛИНИЧЕСКИЕ И МОЛЕКУЛЯРНО-ГЕНЕТИЧЕСКИЕ ХАРАКТЕРИСТИКИ ПАЦИЕНТОВ С МОРФОЛОГИЧЕСКОЙ КАРТИНОЙ ВРОЖДЕННОЙ СТЕРЖНЕВОЙ МИОПАТИИ}

А. А. Козина ${ }^{1,2,5}$, П. А. Шаталов ${ }^{3,5}$, Т. И. Баранич1', С. Б. Артемьева ${ }^{3}$, А. Г. Куприянова ${ }^{3}$, Н. В. Барышникова ${ }^{1,5}$, А. Ю. Красненко В. В. Ильинский ${ }^{1,2,5}$, В. С. Сухоруков ${ }^{1,4}$

${ }^{1}$ Российский национальный исследовательский медицинский университет имени Н. И. Пирогова, Москва, Россия

${ }^{2}$ Научно-исследовательский институт биомедицинской химии имени В. Н. Ореховича, Москва, Россия

${ }^{3}$ Научно-исследовательский клинический институт педиатрии имени академика Ю. Е. Вельтищева,

Российский национальный исследовательский медицинский университет имени Н. И. Пирогова, Москва, Россия

${ }^{4}$ Научный центр неврологии, Москва, Россия

${ }^{5} \mathrm{OOO}$ «Генотек», Москва, Россия

Врожденные стержневые миопатии - это клинически и генетически гетерогенная группа врожденных миопатий, общий гистопатологический признак которых - наличие участков с уменьшенной окислительной активностью при биопсии мышц. Взаимосвязь клинико-генетических, патогенетических и морфологических характеристик этой группы миопатий до конца не изучена. Целью исследования было проанализировать соответствие клиникоморфологических характеристик пациентов с врожденными миопатиями/миодистрофиями и результатов экзомного секвенирования, полученных методами массового параллельного секвенирования (MPS). В исследовании участвовали 8 детей (2 мальчика и 6 девочек 3-14 лет). Морфологический анализ проводили с помощью световой и электронной микроскопии. Молекулярно-генетический анализ проводили с помощью МРS на платсорме HiSeq2500. Мутации были обнаружены в 87,5\% случаев (у 7 из 8 обследованных): у 6 обследованных (8 мутаций) - в генах, ответственных за врожденные стержневые миопатии, и у одного пациента (2 мутации) - в гене LAMA2, ответственном за мерозин-негативную мышечную дистрофию. Доли пациентов с выявленными мутациями в гене RYR1 и мутациями в гене SEPN1 одинаковы и составили 42,86\% среди пациентов с мутациями. Из 10 мутаций, выявленных у обследованных пациентов, 3 мутации описаны впервые: в гене RYR1 - c.7561G>A; в гене SEPN1 - c.485C>A; в гене LAMA2 - p.Cys1136Arg. Совокупность клинических и морфологических признаков, характерных для стержневых миопатий, не позволяет ограничить молекулярно-генетический поиск причины заболевания генами RYR1 и SEPN1, что приводит к необходимости исследовать другие гены, ответственные за развитие врожденных миопатий/миодистрофий, с использованием современных молекулярно-генетических методов.

Ключевые слова: врожденные миопатии центрального стержня, врожденные многостержневые миопатии, ген RYR1, ген SEPN1, ген LAMA2, мышечная биопсия, экзомное секвенирование

Информация о вкладе авторов: А. А. Козина - анализ литературы, интерпретация данных экзомного секвенирования, анализ данных, подготовка рукописи; П. А. Шаталов - сбор данных, проведение морфологического исследования, подготовка рукописи; Т. И. Баранич - проведение морфологического исследования; С. Б. Артемьева - сбор клинических данных, неврологический осмотр пациентов; А. Г. Куприянова - сбор клинических данных; Н. В. Барышникова - анализ литературы, интерпретация данных экзомного секвенирования, анализ данных, подготовка рукописи; А. Ю. Красненко - проведение экзомного секвенирования; В. В. Ильинский - проведение экзомного секвенирования; В. С. Сухоруков планирование исследования, сбор данных.

Соблюдение этических стандартов: исследование одобрено этическим комитетом ФГБОУ ВО РНИМУ имени Н. И. Пирогова (протокол № 172 от 19 февраля 2018 г. ); все участники исследования или их законные представители подписали добровольное информированное согласие.

Для корреспонденции: Анастасия Александровна Козина

Наставнический переулок, д. 17, стр. 1, г. Москва, 105120; doctor@genotek.ru

Статья получена: 07.02.2019 Статья принята к печати: 19.04.2019 Опубликована онлайн: 30.04.2019

DOI: 10.24075/vrgmu.2019.034 
Congenital myopathies constitute a clinically and genetically heterogenous group of neuromuscular disorders with complex pathogenesis, diverse symptoms and different inheritance patterns [1]. In the affected patients, the loss of muscle function is a result of structural pathology of muscle fibers in the absence of dystrophic changes in muscle tissue [2].

There are a few classic forms of congenital myopathies that can be distinguished histologically, the most common being central core disease, nemaline myopathy, multiminicore myopathy, and centronuclear myopathy [2].

Each of these forms has a number of genetic subtypes differing in the severity of presenting symptoms and the patterns of inheritance. This should be accounted for when deciding on an adequate treatment strategy or providing genetic counseling.

Because some congenital myopathies are quite rare, genetically heterogeneous and share symptoms with other neuromuscular disorders, their differential diagnosis and accurate classification pose a challenge, making it difficult to estimate the actual prevalence of these subtypes and their morphological phenotypes or to assess their contribution to the floppy baby syndrome. The limitations of existing sequencing methods complicate the situation even further.

Congenital myopathies have been studied since 1956 when central core disease was first described. However, the etiopathogenesis and the associations between clinical presentations and genetic phenotypes of congenital core myopathies are still not fully clear.

Morphologically, all core myopathies are characterized by areas of reduced oxidative enzyme activity in type 1 muscle fibers, sarcomere disorganization and almost complete depletion of mitochondria visible during a histochemical examination [3, 4].

Core myopathies can be broken down into two major types: central core disease and multiminicore myopathy.

According to the literature, hereditary core myopathies are largely caused by mutations in the genes coding for two proteins of the sarcoplasmic reticulum: the ryanodine receptor (RYR1) and selenoprotein N (SEPN1) [5, 6].

The ryanodine receptor gene (RYR1) is located on chromosome 19q13.1 and comprises 106 exons. The receptor itself is a calcium release channel of the endoplasmic reticulum membrane. In skeletal muscles, this receptor is embedded in the sarcoplasmic reticulum membrane, where it interacts with the dihydropyridine receptor located on plasma membrane invaginations known as transverse tubules. Electrical signals that travel along the sarcolemma activate calcium release from the sarcoplasmic reticulum following the coupling of the two receptors, and the muscle contracts [7-9]. Mutations tend to occur more often in the ryanodine receptor gene (RYR1) than in the gene coding for selenoprotein N (SEPN1). Mutant RYR1 variants are associated with a few pathological conditions, such as an autosomal dominant or autosomal recessive central core disease, in the first place (OMIM entry \#117000), and, less often, multiminicore disease (OMIM entry \#255320) with an autosomal pattern of inheritance $[10,11]$. Mutations in $R Y R 1$ are associated with an increased susceptibility to autosomal dominant malignant hyperthermia (OMIM entry \#145600), a predisposition to severe and potentially lethal adverse reactions to volatile anesthetics and/or muscle relaxants [12].

Central core disease is driven by ultrastructural changes and the loss of enzyme activity (exerted by mitochondrial enzymes, in particular) in the center of skeletal muscle fibers. Histologically, these "cores" differ from the peripheral areas of the fibers, so their morphology is the major diagnostic criterion for this disorder [13] (Fig. 1 and 2). Central core disease usually has an onset in early infancy. Among its typical symptoms are motor development delay, low muscle tone, and weakness of proximal muscles (facial muscles are spared). Skeletal manifestations are not rare, including congenital hip dislocation and scoliosis. Hypotonia does not progress with age.

The SEPN1 gene is located on chromosome 1p36-p35, comprises 13 exons and codes for selenoprotein $\mathrm{N}$, a glycoprotein of the endoplasmic reticulum and a selenium mediator. Selenoprotein is an important component of many metabolic pathways and antioxidant systems. It also helps to maintain calcium homeostasis in muscle tissue by stimulating oxidative enzymes and regulating the oxidative state of ryanodine receptors. Deficit in selenoprotein $\mathrm{N}$ promotes oxidation in myotubes and entails deregulation of superoxide dismutase and catalase. This causes oxidative stress; dysfunctional ryanodine receptors can no longer control calcium release from the endoplasmic reticulum, disrupting calcium homeostasis in muscle tissue [9, 11, 14]. Mutations in SEPN1 are associated with multicore myopathies (OMIM entry \#602771) and congenital rigid spine muscular dystrophy (OMIM entry \#602771), which has a similar phenotype [15]. The inheritance pattern here is autosomal recessive.

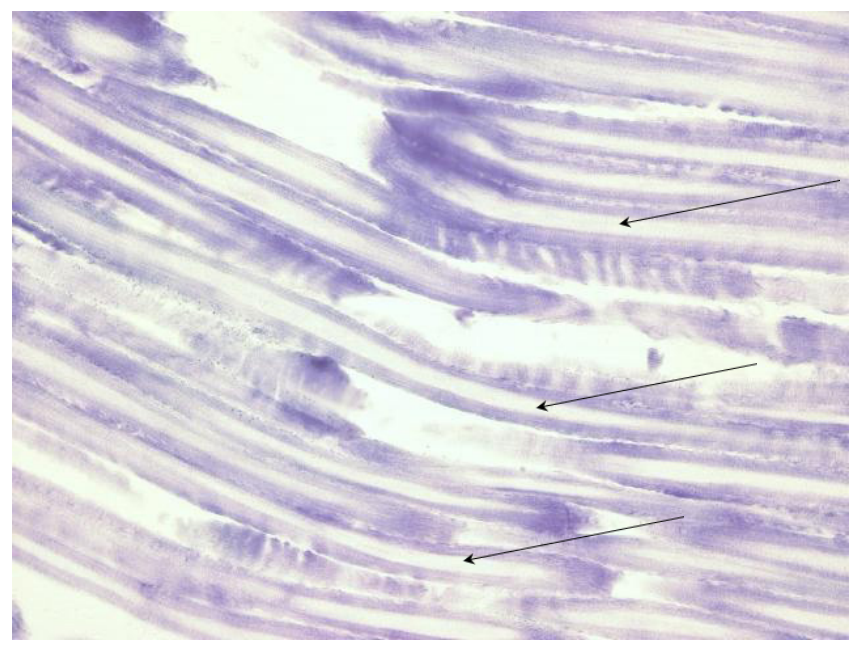

Fig. 1. Skeletal muscle tissue of a 21-year-old patient with congenital central core myopathy. Histochemical analysis of succinate dehydrogenase activity in frozen sections ( $\times 200$; the method was proposed by Sukhorukov VS) using the nitro BT method by Nachlass et al. (1957). The total absence of enzyme activity is observed in almost all longitudinal sections of the examined muscle fibers (the arrows)

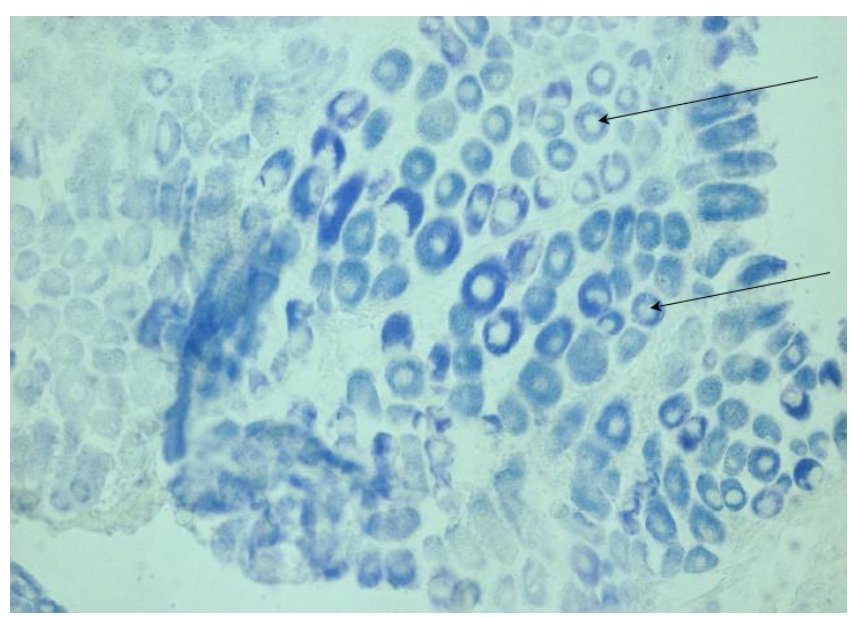

Fig. 2. Skeletal muscle tissue of a 1-year-old patient with congenital central core myopathy Histochemical analysis of succinate dehydrogenase activity in frozen sections ( $\times 200$; the method was proposed by Sukhorukov VS) using the nitro BT method by Nachlass et al. (1957). The total absence of enzyme activity is observed in almost all cross-sections of the examined muscle fibers (the arrows) 
Histologically, multicore myopathies are characterized by the presence of multiple cores in skeletal muscle fibers that do not necessarily affect the center of the fiber (Fig. 3). In $R Y R 1$-associated multiminicore myopathy, the cores are quite massive [9, 11]. In SEPN1-associated myopathy, minicores are abundantly present in the muscle tissue $[9,11]$.

Multiminicore myopathy is a congenital myopathy that develops in infancy and manifests itself as a floppy baby syndrome. The symptoms include low muscle tone, delayed motor development, proximal muscle weakness, spina deformities, early onset of scoliosis, and chest deformities. Facial muscle weakness is also typical.

The similarity of clinical presentations between core myopathies and other congenital myopathies, the complexity of these diseases, and the existence of different combinations of muscle tissue abnormalities complicate the differential diagnosis. The diagnosis of congenital myopathy is based on the assessment of both clinical and morphological presentations and the results of molecular-genetic tests. Patients with structural myopathies do not always share the same clinical and morphological phenotype. Although such myopathies are linked to the mutations in the RYR1 and SEPN1 genes, there is a hypothesis suggesting that other genes may also be involved; some authors also hypothesize the polygenic nature of these neuromuscular conditions [2]. In light of this, it may be relevant to explore clinical, morphological and genetic aspects of congenital core myopathies in parallel.

The aim of this study was to compare clinical and morphological features and the results of massively parallel exome sequencing in patients with clinical symptoms and histological evidence of congenital core myopathies.

\section{METHODS}

The study was carried out in 8 children ( 2 boys and 6 girls) aged 3 to 14 years. The study included patients of both sexes with no family history of neurological disorders who were diagnosed with congenital myopathy and whose histological samples suggested core myopathy; the patients also underwent molecular genetic testing. The following exclusion criteria were applied: the absence of morphological signs of core myopathies in biopsy samples.

The patients' medical records were analyzed. Biopsy samples were studied by light and electron microscopy following the protocols supplied by the manufacturers. Prior to light microscopy, the samples were either paraffinized or frozen and then stained.

1. Fresh tissue sections were prepared by immersing the samples in liquid nitrogen and then slicing them on a Microm HM 505 N cryostat microtome (Microm Tech.; USA). Paraffin sections were prepared by fixing biopsy material in 10\% neutral ( $\mathrm{pH}$ 7.4) buffered formalin following the manufacturer's protocol and then slicing it on the microtome.

2. Hematoxylin-eosin staining of both frozen and paraffinized sections was performed according to the standard protocol. Succinate dehydrogenase activity in the frozen sections was measured using the standard nitro blue tetrazolium-based technique proposed by Nachlass in 1957 [16].

3. Prior to electron microscopy, the samples less than $1 \mathrm{~mm}^{3}$ in size were prefixed in a $2.5 \%$ solution of glutaraldehyde in a phosphate buffer $(\mathrm{pH} 7.4)$ at $0{ }^{\circ} \mathrm{C}$. After being washed in a phosphate buffer $(\mathrm{pH} 7.4)$, the samples were fixed in $1 \%$ osmium tetroxide at $2-4{ }^{\circ} \mathrm{C}$ for $1 \mathrm{~h}$. Then, the samples were dehydrated in a series of ascending ethanol concentrations, washed in acetone 3 times and embedded in Epon resin using a technique proposed by Luft [17]. The slices were prepared on the REICHERT Nr. 321850/E ultratome (Reichert tech.; Austria) and stained with lead citrate and sodium uranyl acetate as proposed by Reynolds in [18]. The sections were examined under a transmission electron microscope JEOL JEM-100B (Jeol LTD; Japan).

Exome sequencing was performed using the HiSeq2500 platform (lllumina; USA) according to the manufacturer's protocol.

1. Amplification products were labeled using the BigDye Terminator v3.1 Cycle Sequencing Kit (Thermo Fisher Scientific; USA) according to the manufacturer's protocol. Sanger sequencing was carried out on an ABI PRISM 3500 Genetic Analyzer (Applied Biosystems; USA) according to the manufacturer's protocol.

2. Sequencing data was processed in Cutadapt ver. 1.14 (Cutadapt; USA), BWA ver. 1.14 (Illumina; USA), FastQC ver. 0.11.5 (Illumina; USA), GATK HaplotypeCaller ver. 3.7 (GATK HaplotypeCaller; USA), and snpEff ver. 4.3p (SnpEff; USA). Pathogenicity and conservation of mutations were assessed based on the data extracted from dbNSFP, Clinvar, OMIM, and HGMD databases. SIFT 1.03 (SIFT; USA) and Polyphen2 ver. 2.2.2 (Polyphen2; USA) utilities were used to predict potential pathogenicity of the detected mutations. Information about the frequency of the mutations was obtained from the 1000 Genomes project, ExAC and other databases. The annotations and pathogenicity of the detected mutations were predicted as proposed by the Standards and Guidelines for the interpretation of sequence variants developed by ACMG, AMP and CAP [19].

3. Clinical interpretation of sequencing data was aided by OMIM (https://omim.org/), Varsome (https://varsome.com/), ClinVar (https://www.ncbi.nlm.nih.gov/clinvar/), The Human Gene Mutation Database (http://www.hgmd.cf.ac.uk/ac/index.php), and some other genetic databases according to the guidelines for MPS data interpretation [20].

\section{RESULTS}

The patients had similar clinical symptoms typical of congenital structural myopathies: the floppy baby syndrome in infancy and delayed motor development. Gait was also affected: some patients were unable to walk on their own; spinal deformities were observed. Neurological symptoms included low muscle tone and strength, weak or absent tendon reflexes in the upper and lower limbs. Biochemistry tests revealed normal creatine

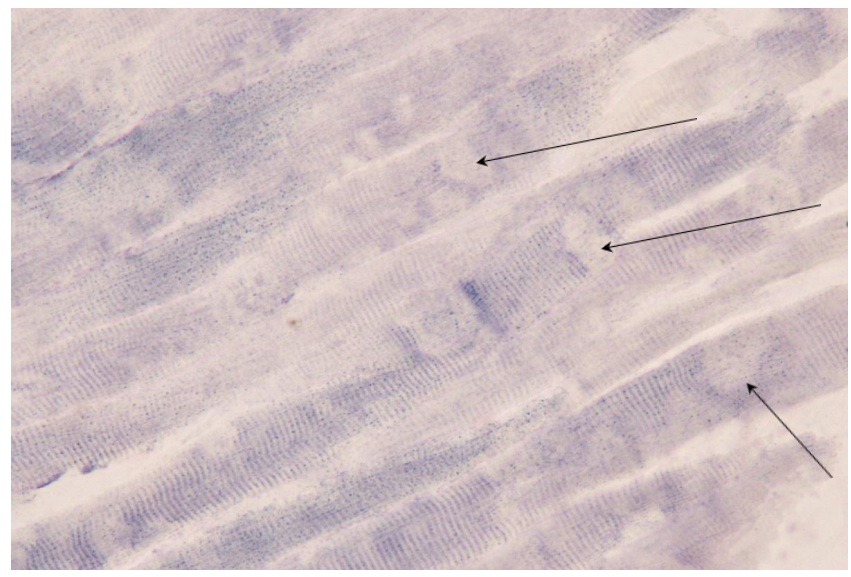

Fig. 3. Skeletal muscle tissue of a 3.5-year-old patient with congenital multiminicore myopathy Histochemical analysis of succinate dehydrogenase activity in frozen sections ( $\times 200$; the method was proposed by Sukhorukov VS) using the nitro BT method by Nachlass et al. (1957). Cores are abundant in almost all longitudinal sections of the examined muscle fibers (the arrows) 
phosphokinase (CPK) levels in 3 children under 5 years of age; in 5 children aged 7 to 14 years CPK was either high but within the reference range or slightly elevated above the norm (Table 1). Cores were observed in the biopsy samples of 5 patients (patients 1, 2, 3, 7, and 8) diagnosed with central core disease; histological analysis suggested multiminicore myopathy in 3 patients (patients 4, 5, and 6).

Mutations were detected in $87.5 \%$ of cases (7 of 8 examined patients). Six children had mutant variants of RYR1 and SEPN1 implicated in congenital myopathy. One patient had a mutation in LAMA2 associated with merosin-deficient muscular dystrophy (Table 2).

\section{DISCUSSION}

Sequencing data are well-correlated with the clinical presentations and morphological features of the patients: in 3 patients with a morphological phenotype of central core disease (patients 1, 2 and 3), mutations were observed in gene $R Y R 1$; 3 patients with a morphological phenotype of multicore myopathy (patients 4,5 and 6) had mutations in gene SEPN1 (Table 2). The proportions of patients with mutations in RYR1 and SEPN1 were equal and amounted to $42.86 \%$ each relative to all the examined patients with mutations.

Three patients had 4 mutations in RYR1. Of those mutant variants, 3 were not described previously, including c.11798A>G, c. $14387 A>G$ and c. $14581 C>T$ [21, 22, 23].

According to the literature, mutations c.11798 $A>G$ and c. $14387 A>G$ are associated with sporadic central core disease; our patients who carried them (patients 1 and 2, respectively) were also heterozygous.

Patient 3 had 2 mutations (c. 14581C>T and c.7561G>A) in the RYR1 gene that were presumably compound heterozygous, which suggests an autosomal recessive pattern of inheritance. Mutation c. $14581 \mathrm{C}>\mathrm{T}$ is known to occur in patients with sporadic central core disease but can also be recessive [27]. Mutation c.7561G>A was not described previously. The presence of 2 mutations in one patient suggests an autosomal recessive pattern of inheritance.

Three patients had 4 mutations in the SEPN1 gene. Mutations c.611dupA, c.713dupA, and c.583G>A were described previously $[24,25]$

C.611dupA is a frameshift mutation that produces a shortened dysfunctional protein. This mutation was homozygous in patient 5 , which is consistent with an autosomal recessive pattern of inheritance.

Another frameshift mutation c.713dupA was detected in a compound heterozygous patient 4 . It is described as a cause of rigid spine muscular dystrophy (OMIM entry \#602771) in homo- and heterozygous French patients [24]. Genetic variant $\mathrm{c} .583 \mathrm{G}>\mathrm{A}$ carried by patient 4 was characterized by the prediction software as likely pathogenic; genetic databases refer to it as benign. Therefore, its role in the disease still needs to be elucidated.

Mutation c.485C $>\mathrm{A}$ is a previously unknown mutation that was heterozygous in patient 6 . This means that multicore myopathy diagnosed in this patient cannot be confirmed by the genetic test, although morphological and clinical findings suggest otherwise. At the same time, we cannot rule out SEPN1- associated multicore myopathy because mutations in the second allele of the gene might have been overlooked due to the technical limitations of massive parallel sequencing.

Sequencing revealed the absence of RYR1 and SEPN1 mutations in 2 patients (patients 7 and 8) who had been diagnosed with myopathy/myodystrophy before the genetic test and had a morphological phenotype of central core disease.

Table 1. Symptoms of the patients with morphological signs of core myopathies revealed by histological analysis

\begin{tabular}{|c|c|c|c|c|c|c|c|c|}
\hline Symptoms / Patient & 1 & 2 & 3 & 4 & 5 & 6 & 7 & 8 \\
\hline $\begin{array}{l}\text { Weight and height } \\
\text { at birth }(\mathrm{g} / \mathrm{cm})\end{array}$ & $3310 / 50$ & $3540 / 55$ & $2480 / 48$ & $2800 / 49$ & $3780 / 53$ & $3060 / 50$ & $2859 / 50$ & $3500 / 54$ \\
\hline $\begin{array}{c}\text { Congenital hip } \\
\text { dislocation/dysplasia }\end{array}$ & - & - & + (dislocation) & - & - & - & + (dysplasia) & - \\
\hline $\begin{array}{l}\text { Delayed motor } \\
\text { development }\end{array}$ & - & + & + & + & + & - & ++ & + \\
\hline Muscle strength & 4 points & 4 points & 4 points & $2-3$ points & 4 points & $2-3$ points & 1-2 points & $3-4$ points \\
\hline Gait & Myopathic & $\begin{array}{l}\text { Cannot walk at } \\
\text { the moment }\end{array}$ & Myopathic & Myopathic & Myopathic & $\begin{array}{l}\text { Has not walked } \\
\text { since } 9 \text { years } \\
\text { of age }\end{array}$ & $\begin{array}{l}\text { Was never } \\
\text { able to walk }\end{array}$ & Myopathic \\
\hline Spinal deformities & $\begin{array}{c}\text { Thoracic } \\
\text { hyperkyphosis }\end{array}$ & $\begin{array}{c}\text { Thoracic } \\
\text { hyperkyphosis }\end{array}$ & $\begin{array}{l}\text { Curvature of } \\
\text { the spine }\end{array}$ & $\begin{array}{l}\text { Thoracic and } \\
\text { lumbar spine } \\
\text { scoliosis }\end{array}$ & Rigid spine & Kyphoscoliosis & Scoliosis & Scoliosis \\
\hline Joint contractures & Ankle joint & - & - & $\begin{array}{l}\text { Hip, knee and } \\
\text { ankle joints }\end{array}$ & Ankle joint & $\begin{array}{l}\text { Hip, knee and } \\
\text { ankle joint }\end{array}$ & $\begin{array}{l}\text { Hip, knee, ankle, } \\
\text { elbow and wrist } \\
\text { joints }\end{array}$ & $\begin{array}{l}\text { Hip, knee } \\
\text { and ankle } \\
\text { joint }\end{array}$ \\
\hline $\begin{array}{l}\text { Reduced reflexes in } \\
\text { upper and lower limbs }\end{array}$ & + & + & + & ++ & + & ++ & ++ & ++ \\
\hline Breathing problems & + & +- & N/A & +++ & + & + & N/A & + \\
\hline $\begin{array}{l}\text { Reduced intellectual } \\
\text { capacity }\end{array}$ & - & + & +- & - & - & - & - & - \\
\hline Additional symptoms & - & - & - & $\begin{array}{c}\text { Severe } \\
\text { malnutrition }\end{array}$ & - & $\begin{array}{l}\text { Ptosis of } \\
\text { the upper } \\
\text { eyelid, chronic } \\
\text { hypoventilation } \\
\text { syndrome }\end{array}$ & $\begin{array}{l}\text { Weak facial } \\
\text { muscles, } \\
\text { occipital } \\
\text { epilepsy }\end{array}$ & - \\
\hline $\begin{array}{c}\text { CPK levels, un/L } \\
\text { (normal range of } \\
15-190 \text { ) }\end{array}$ & 78 & 66 & 79 & 188 & 284 & 174 & 290 & 194 \\
\hline
\end{tabular}

Note: 1 - boy, 4 years; 2 - girl, 3 years; 3 - girl, 5 years; 4 - girl, 8 years; 5 - boy, 7 years; $6-$ girl, 11 years; 7 - girl, 14 years; 8 - girl, 7 years. 
Table 2. A list of mutations detected in the patients with morphological signs of core myopathy

\begin{tabular}{|c|c|c|c|c|c|c|c|c|}
\hline \multirow[b]{2}{*}{ Patient } & \multirow{2}{*}{$\begin{array}{l}\text { Diagnosis before the } \\
\text { genetic test }\end{array}$} & \multirow[b]{2}{*}{ Gene } & \multicolumn{5}{|c|}{ Detected mutations and genotypes } & \multirow[b]{2}{*}{ Reference } \\
\hline & & & $\begin{array}{c}\text { Exon } \\
\text { № }\end{array}$ & $\begin{array}{l}\text { Transcript } \\
\text { № }\end{array}$ & Nucleotide & $\begin{array}{l}\text { Amino acid } \\
\text { substitution }\end{array}$ & Genotype & \\
\hline 1 & $\begin{array}{c}\text { Congenital structural } \\
\text { myopathy. Central core } \\
\text { disease }\end{array}$ & $R Y R 1,19 \mathrm{q} 13.2$ & 86 & NM_000540.2 & c. $11798 A>G$ & p.Tyr3933Cys & Heterozygous & [21] \\
\hline 2 & Congenital myopathy & $R Y R 1,19 \mathrm{q} 13.2$ & 100 & NM_000540.2 & c. $14387 A>G$ & p.Tyr4796Cys & Heterozygous & [22] \\
\hline \multirow{2}{*}{3} & \multirow{2}{*}{$\begin{array}{l}\text { Congenital structural } \\
\text { myopathy }\end{array}$} & \multirow{2}{*}{$R Y R 1,19 \mathrm{q} 13.2$} & 101 & NM_000540.2 & c. $14581 \mathrm{C}>\mathrm{T}$ & p.Arg4861Cys & Heterozygous & [23] \\
\hline & & & 47 & NM_000540.2 & c. $7561 \mathrm{G}>\mathrm{A}$ & p.Val2521Met & Heterozygous & Not described \\
\hline \multirow{2}{*}{4} & \multirow{2}{*}{ Congenital myopathy } & \multirow{2}{*}{ SEPN1, 1p36.11 } & 5 & NM_020451.2 & c.713dupA & p.Asn238fs & Heterozygous & [24] \\
\hline & & & 5 & NM_020451.2 & c. $583 G>A$ & p.Ala195Thr & Heterozygous & [25] \\
\hline 5 & Congenital myopathy & SEPN1, 1p36.11 & 4 & NM_206926.1 & c.611dupA & p.Asn204fs & Homozygous & [24] \\
\hline 6 & Congenital myopathy & SEPN1, 1p36.11 & 4 & NM_206926.1 & c. $485 \mathrm{C}>\mathrm{A}$ & p.Ser162* & Heterozygous & Not described \\
\hline \multirow{2}{*}{7} & \multirow{2}{*}{$\begin{array}{l}\text { Congenital structural } \\
\text { myopathy }\end{array}$} & \multirow{2}{*}{ LAMA2, 6q22.33 } & 50 & NM_000426.3 & c. $7147 \mathrm{C}>\mathrm{T}$ & p.Arg2383* & Heterozygous & {$[26,28]$} \\
\hline & & & 23 & NM_000426.3 & c. $3406 \mathrm{~T}>\mathrm{C}$ & p.Cys1136Arg & Heterozygous & Not described \\
\hline 8 & $\begin{array}{l}\text { Congenital muscular } \\
\text { dystrophy }\end{array}$ & - & - & - & Undetected & Undetected & Unknown & - \\
\hline
\end{tabular}

Note: 1 - boy, 4 years; 2 - girl, 3 years; 3 - girl, 5 years; 4 - girl, 8 years; 5 - boy, 7 years; 6 - girl, 11 years; 7 - girl, 14 years; 8 — girl, 7 years; * — a stop codon

Patient 7 had 2 presumably compound heterozygous mutations in the LAMA2 gene (14.28\% of total detected mutations). Mutant LAMA2 variants are associated with type 23 limb-girdle muscular dystrophy (OMIM entry \#618138) and congenital merosin-deficient muscular dystrophy (OMIM entry \#607855) that follow a dominant recessive pattern of inheritance.

The LAMA2 mutation c.7147C>T (p.Arg2383*) detected in patient 7 results in the synthesis of a shortened dysfunctional protein. Its homozygous variant was previously described in a 4-year-old girl [28] who had typical symptoms of type A merosin-deficient muscular dystrophy, including congenital hypotonia, muscle weakness, elevated CPK of 1,556 IU/L and white matter abnormalities seen on MRI. Besides, patients afflicted with this disorder can have seizures and structural brain abnormalities. In patients with congenital laminin alpha 2 deficient muscular dystrophy, severity of the clinical symptoms varies, but the causes underlying this phenomenon are not fully understood and might be associated with RNA missplicing [26].

The second detected mutation in the LAMA2 gene is a nonsynonymous substitution c.3406T>C (p.Cys1136Arg) that was not described previously. Nonsynonymous substitutions can result in the formation of alternative splice sites, synthesis of new protein isoforms and conformational changes to the protein structure that affect its function. Therefore, the role of the detected mutation in the development of the disease needs to be elucidated.

The symptoms observed in patient 7 were different from those described above. The differential diagnosis included Werdnig-Hoffmann disease and congenital structural myopathy. Epilepsy was benign and was not considered a symptom. Histological findings suggested central core disease. However, the clinical, morphological and genetic data collected from the patient should not be regarded as controversial. The mechanism underlying the formation of cores in muscle fibers and the time it takes remain understudied [2]. Formation of cores might be the result of disrupted mitochondrial activity. The study of muscle tissue biopsy samples obtained from patients with different forms of congenital myopathy/myodystrophy at different stages of the disease will broaden our knowledge of the interactions and the order of involvement of proteins and muscle tissue components into the pathological process.
No clinically relevant genetic variants associated with neuromuscular disorders were detected in patient 8. However, this might have been due to the technical limitations of massive parallel sequencing.

The absence of mutations in the RYR 1 gene in 2 patients (7 and 8) with a preliminary diagnosis of congenital myopathy/ myodystrophy and a morphological phenotype of central core disease confirms the need for extensive molecular genetic testing in such patients. At the same time, in the presence of additional clinical symptoms rarely seen in a particular condition (in our case, patient 7 had seizures) the probability of detecting other molecular-genetic abnormalities increases. This also speaks for the necessity of research into the mechanisms underlying congenital myopathies and myodystrophy and their morphological manifestations.

We have also discovered correlations between CPK activity and the detected mutations. As a rule, CPK levels suggest the location of lesions in patients with neuromuscular disorders, their acuteness and duration. RYR1 mutations were present only in the patients with normal CPK levels. The highest CPK was observed in the patient with a homozygous SEPN1 mutation and also in the patient who carried mutations in the LAMA2 gene associated with the most severe form of congenital myopathy. Perhaps, CPK can be used to measure pathogenicity of a molecular-genetic abnormality (the presence/ absence of a protein or the loss of its function) that leads to the disease and causes secondary myodystrophy.

\section{CONCLUSIONS}

Our findings confirm that myopathies characterized by the presence of cores in muscle fibers are genetically heterogenous. Mutations in the RYR1 and SEPN1 genes are the major genetic cause of core myopathies in Russian patients, which is consistent with the findings of our foreign colleagues. The majority (75\%, 6 of 8 patients) of RYR1 and SEPN1 mutant variants carried by our patients were described previously. Two previously unknown mutations need to be studied further in order to elucidate their clinical relevance. Our work shows that histological findings cannot be used as the only criterion for the differential diagnosis of congenital myopathies. Morphological phenotypes typical for core myopathies can also be seen in other congenital myopathies 
or myodystrophy. This means that clinical, morphological and genetic correlations should be studied in-depth to understand the mechanisms underlying the development of the disease and to come up with effective therapies in the case of complications. The absence of mutations in the genes implicated in congenital myopathies in patients with clinical symptoms and morphological signs of core myopathies requires further investigation.

\section{References}

1. Bonne G, Rivier F, Hamroun D. The 2019 version of the gene table of neuromuscular disorders (nuclear genome). Neuromuscul Disord. 2018 Dec; 28 (12): 1031-63. DOI: 10.1016/j.nmd.2018.09.006.

2. Suhorukov VS, Harlamov DA. Vrozhdennye miopatii. M.: OOO Press-Art, 2010; $155 \mathrm{~s}$

3. Jungbluth H, Sewry CA, Muntoni F. Core Myopathies. Semin Pediatr Neurol. 2011 Dec; 18 (4): 239-49. DOI: 10.1016/j. spen.2011.10.005

4. Harlamov DA, Baranich TI, Glinkina WV, Brydun AV. Mitohondrial'nye narushenija pri vrozhdennyh miopatijah. Rossijskij vestnik perinatologii i pediatrii. 2014; 59 (3): 32-38.

5. MacLennan DH, Zorzato F, Fujii J, Otsu K, Phillips M, Lai FA, et al. Cloning and localization of the human calcium release channel (ryanodine receptor) gene to the proximal long arm (cen-q13.2) of human chromosome 19. (Abstract) Am J Hum Genet [Internet]. 1989; 45 (suppl.)

6. Moghadaszadeh B, Petit N, Jaillard C, Brockington M, Roy SQ, Merlini L, et al. Mutations in SEPN1 cause congenital muscular dystrophy with spinal rigidity and restrictive respiratory syndrome. Nature Genet. 2001; (29): 17-8.

7. Melnikov KN. Raznoobrazie i svojstva kal'cievyh kanalov vozbudimyh membran. Psihofarmakologija i biologicheskaja narkologija. 2006; (1-2): 1139-51.

8. Chen W, Koop A, Liu Y, Guo W, Wei J, Wang R, et al. Reduced threshold for store overload-induced $\mathrm{Ca}^{2+}$ release is a common defect of RyR1 mutations associated with malignant hyperthermia and central core disease. Biochem J. 2017 Aug 7; 474 (16): 2749-61. DOI: 10.1042/BCJ20170282. PMID: 28687594.

9. Suhorukov VS, Harlamov DA, Shatalov PA, Harabadze MN, Yablonskaya Ml, Brydun AV i dr. Vrozhdennaja «mnogosterzhnevaja» miopatija. Rossijskij vestnik perinatologii pediatrii. 2012; 57 (4-1): 90-3.

10. Jungbluth $\mathrm{H}$, Zhou $\mathrm{H}$, Hartley L, Halliger-Keller $B$, Messina $S$, Longman $\mathrm{C}$, et al. Minicore myopathy with ophthalmoplegia caused by mutations in the ryanodine receptor type 1 gene. Neurology. 2005 Dec 27; 65 (12): 1930-5. PMID: 16380615.

11. Jungbluth H. Multi-minicore Disease. Orphanet J Rare Dis. 2007; (2): $31-45$.

12. McCarthy EJ. Malignant hyperthermia: pathophysiology, clinical presentation, and treatment. AACN Clin Issues. 2004 Apr-Jun; 15 (2): 231-7. PMID: 15461040.

13. Suhorukov VS, Shatalov PA, Harlamov DA, Brydun AV. Izmenenija mitohondrij pri vrozhdennoj miopatii "central'nogo sterzhnja» u detej. Rossijskij vestnik perinatologii i pediatrii. 2011; 56 (4): 84-7.

14. Lescure A, Rederstorff M, Krol A, et al. Selenoprotein function and muscle disease. Biochim Biophys Acta. 2009; (1790): 1569-74.

15. Engel AG, Gomes MR. Congenital myopathy associated with multifocal degeneration of muscle fibers. Trans Am Neurology Assoc. 1966; (91): 222-3.

\section{Литература}

1. Bonne G, Rivier F, Hamroun D. The 2019 version of the gene table of neuromuscular disorders (nuclear genome). Neuromuscul Disord. 2018 Dec; 28 (12): 1031-63. DOI: 10.1016/j.nmd.2018.09.006.

2. Сухоруков В. С., Харламов Д. А. Врожденные миопатии. М.: ООО Пресс-Арт, 2010; 155 с.

3. Jungbluth H, Sewry CA, Muntoni F. Core Myopathies. Semin
16. Pirs A. Gistohimiya. M.: Izd-vo inostrannoj literatury, 1962; $963 \mathrm{~s}$.

17. Luft JH. Improvements in epoxy resin embedding methods. J Biophys Biochem Cytol. 1961; (9): 409-14.

18. Reynolds ES. The use of lead citrate at high $\mathrm{pH}$ as an electronopaque stain in electron microscopy. J Cell Biol. 1963; (17): 208-12.

19. Richards S, Aziz N, Bale S, Bick D, Das S, Gastier-Foster J. et al. Standards and guidelines for the interpretation of sequence variants: a joint consensus recommendation of the American College of Medical Genetics and Genomics and the Association for Molecular Pathology. Genet Med. 2015;17 (5): 405-23.

20. Ryzhkova OP, Kardymon OL, Prohorchuk EB, Konovalov FA Maslennikov AB, Stepanov VA i dr. Rukovodstvo po interpretaci dannyh, poluchennyh metodami massovogo parallel'nogo sekvenirovanija (MPS). Medicinskaja genetika. 2017; 16 (7): 4-17.

21. Duarte ST, Oliveira J, Santos R, Pereira P, Barroso C, Conceição I, et al. Dominant and recessive RYR1 mutations in adults with core lesions and mild muscle symptoms. Muscle Nerve. $2011 \mathrm{Jul}$; 44 (1): 102-8. DOI: 10.1002/mus.22009. PMID: 21674524.

22. Monnier N, Romero NB, Lerale J, Nivoche Y, Qi D, MacLennan DH, et al. An autosomal dominant congenital myopathy with cores and rods is associated with a neomutation in the RYR1 gene encoding the skeletal muscle ryanodine receptor. Hum Mol Genet. 2000 Nov 1; 9 (18): 2599-608. PMID: 11063719.

23. Davis MR, Haan E, Jungbluth H, Sewry C, North K, Muntoni F, et al. Principal mutation hotspot for central core disease and related myopathies in the C-terminal transmembrane region of the RYR1 gene. Neuromuscul Disord. 2003 Feb; 13 (2): 151-7. PMID: 12565913.

24. Ferreiro A, Quijano-Roy S, Pichereau C, Moghadaszadeh B, Goemans N, Bönnemann C, et al. Mutations of the seleno-protein $\mathrm{N}$ gene, which is implicated in rigid spine muscular dystrophy, cause the classical phenotype of multiminicore disease: reassessing the nosology of early-onset myopathies. Am J Hum Genet. 2002 Oct; 71 (4): 739-49. PMID: 12192640.

25. Tajsharghi H, Darin N, Tulinius M, Oldfors A. Early onset myopathy with a novel mutation in the Selenoprotein $\mathrm{N}$ gene (SEPN1). Neuromuscul Disord. 2005 Apr; 15 (4): 299-302. PMID: 15792869.

26. Pegoraro E, Fanin M, Trevisan CP, Angelini C, Hoffman EP. A novel laminin alpha 2 isoform in severe laminin alpha 2 deficient congenital muscular dystrophy. Neurology. 2000 Oct 24; 55 (8): 1128-34. PMID: 11071490.

27. Kossugue PM, Paim JF, Navarro MM, Silva HC, Pavanello RC, Gurgel-Giannetti J, et al. Central core disease due to recessive mutations in RYR1 gene: is it more common than described? Muscle Nerve. 2007 May; 35 (5): 670-4. PMID: 17226826.

28. He Z, Luo X, Liang L, Li P, Li D, Zhe M. Merosin-deficient congenital muscular dystrophy type 1A: A case report. Exp Ther Med. 2013 Nov; 6 (5): 1233-6. PMID: 24223650

Pediatr Neurol. 2011 Dec; 18 (4): 239-49. DOI: 10.1016/j. spen.2011.10.005

4. Харламов Д. А., Баранич Т. И., Глинкина В. В., Брыдун А. В Митохондриальные нарушения при врожденных миопатиях. Российский вестник перинатологии и педиатрии. 2014; 59 (3): 32-38. 
5. MacLennan DH, Zorzato F, Fujii J, Otsu K, Phillips M, Lai FA, et al Cloning and localization of the human calcium release channel (ryanodine receptor) gene to the proximal long arm (cen-q13.2) of human chromosome 19. (Abstract) Am J Hum Genet [Internet]. 1989; 45 (suppl.).

6. Moghadaszadeh B, Petit N, Jaillard C, Brockington M, Roy SQ, Merlini L, et al. Mutations in SEPN1 cause congenital muscular dystrophy with spinal rigidity and restrictive respiratory syndrome. Nature Genet. 2001; (29): 17-8.

7. Мельников К. Н. Разнообразие и свойства кальциевых каналов возбудимых мембран. Психофармакология и биологическая наркология. 2006; (1-2): 1139-51.

8. Chen W, Koop A, Liu Y, Guo W, Wei J, Wang R, et al. Reduced threshold for store overload-induced $\mathrm{Ca}^{2+}$ release is a common defect of RyR1 mutations associated with malignant hyperthermia and central core disease. Biochem J. 2017 Aug 7; 474 (16): 2749-61. DOI: 10.1042/BCJ20170282. PMID: 28687594.

9. Сухоруков В. С., Харламов Д. А., Шаталов П. А., Харабадзе М. Н., Яблонская М. И., Брыдун А. В. и др. Врожденная «многостержневая" миопатия. Российский вестник перинатологии и педиатрии. 2012; 57 (4-1): 90-3.

10. Jungbluth $\mathrm{H}$, Zhou $\mathrm{H}$, Hartley $\mathrm{L}$, Halliger-Keller $\mathrm{B}$, Messina $\mathrm{S}$, Longman $\mathrm{C}$, et al. Minicore myopathy with ophthalmoplegia caused by mutations in the ryanodine receptor type 1 gene. Neurology. 2005 Dec 27; 65 (12): 1930-5. PMID: 16380615.

11. Jungbluth H. Multi-minicore Disease. Orphanet J Rare Dis. 2007; (2): $31-45$.

12. McCarthy EJ. Malignant hyperthermia: pathophysiology, clinical presentation, and treatment. AACN Clin Issues. 2004 Apr-Jun 15 (2): 231-7. PMID: 15461040.

13. Сухоруков В. С., Шаталов П. А., Харламов Д. А., Брыдун А. В. Изменения митохондрий при врожденной миопатии «центрального стержня» у детей. Российский вестник перинатологии и педиатрии. 2011; 56 (4): 84-7.

14. Lescure A, Rederstorff M, Krol A, et al. Selenoprotein function and muscle disease. Biochim Biophys Acta. 2009; (1790): 1569-74.

15. Engel AG, Gomes MR. Congenital myopathy associated with multifocal degeneration of muscle fibers. Trans Am Neurology Assoc. 1966; (91): 222-3.

16. Пирс Э. Гистохимия. М.: Изд-во иностранной литературы, 1962; $963 \mathrm{c}$

17. Luft $\mathrm{JH}$. Improvements in epoxy resin embedding methods. $J$ Biophys Biochem Cytol. 1961; (9): 409-14.

18. Reynolds ES. The use of lead citrate at high $\mathrm{pH}$ as an electronopaque stain in electron microscopy. J Cell Biol. 1963; (17): 208-12.
19. Richards S, Aziz N, Bale S, Bick D, Das S, Gastier-Foster J. et al. Standards and guidelines for the interpretation of sequence variants: a joint consensus recommendation of the American College of Medical Genetics and Genomics and the Association for Molecular Pathology. Genet Med. 2015;17 (5): 405-23.

20. Рыжкова О. П., Кардымон О. Л., Прохорчук Е. Б., Коновалов Ф. А. Масленников А. Б., Степанов В. А. и др. Руководство по интерпретации данных, полученных методами массового параллельного секвенирования (MPS). Медицинская генетика. 2017; 16 (7): 4-17.

21. Duarte ST, Oliveira J, Santos R, Pereira P, Barroso C, Conceição I, et al. Dominant and recessive RYR1 mutations in adults with core lesions and mild muscle symptoms. Muscle Nerve. $2011 \mathrm{Jul} ; 44$ (1): 102-8. DOI: 10.1002/mus.22009. PMID: 21674524

22. Monnier N, Romero NB, Lerale J, Nivoche $Y$, Qi D, MacLennan DH, et al. An autosomal dominant congenital myopathy with cores and rods is associated with a neomutation in the RYR1 gene encoding the skeletal muscle ryanodine receptor. Hum Mol Genet. 2000 Nov 1: 9 (18): 2599-608. PMID: 11063719.

23. Davis MR, Haan E, Jungbluth $H$, Sewry $C$, North $K$, Muntoni F, et al. Principal mutation hotspot for central core disease and related myopathies in the C-terminal transmembrane region of the RYR1 gene. Neuromuscul Disord. 2003 Feb; 13 (2): 151-7. PMID: 12565913.

24. Ferreiro A, Quijano-Roy S, Pichereau C, Moghadaszadeh B, Goemans N, Bönnemann C, et al. Mutations of the seleno-protein $\mathrm{N}$ gene, which is implicated in rigid spine muscular dystrophy, cause the classical phenotype of multiminicore disease: reassessing the nosology of early-onset myopathies. Am J Hum Genet. 2002 Oct; 71 (4): 739-49. PMID: 12192640.

25. Tajsharghi $\mathrm{H}$, Darin N, Tulinius M, Oldfors A. Early onset myopathy with a novel mutation in the Selenoprotein $\mathrm{N}$ gene (SEPN1). Neuromuscul Disord. 2005 Apr; 15 (4): 299-302. PMID: 15792869.

26. Pegoraro E, Fanin M, Trevisan CP, Angelini C, Hoffman EP. A novel laminin alpha 2 isoform in severe laminin alpha 2 deficient congenital muscular dystrophy. Neurology. 2000 Oct 24; 55 (8): 1128-34. PMID: 11071490.

27. Kossuque PM, Paim JF, Navarro MM, Silva HC, Pavanello RC, Gurgel-Giannetti J, et al. Central core disease due to recessive mutations in RYR1 gene: is it more common than described? Muscle Nerve. 2007 May; 35 (5): 670-4. PMID: 17226826.

28. He Z, Luo X, Liang L, LiP, Li D, Zhe M. Merosin-deficient congenital muscular dystrophy type 1A: A case report. Exp Ther Med. 2013 Nov; 6 (5): 1233-6. PMID: 24223650. 